Article

\title{
An Overview of the Transition to a Circular Economy in Emilia-Romagna Region, Italy Considering Technological, Legal-Regulatory and Financial Points of View: A Case Study
}

\author{
Daniela Sani ${ }^{1}$, Sara Picone ${ }^{1}$, Augusto Bianchini ${ }^{2, *(\mathbb{D})}$, Fabio Fava ${ }^{3}$, Patricia Guarnieri ${ }^{4}$ and Jessica Rossi ${ }^{2}$ (D) \\ 1 ART-ER Attractiveness Research Territory, 40129 Bologna, Italy; daniela.sani@art-er.it (D.S.); \\ sara.picone@art-er.it (S.P.) \\ 2 Department of Industrial Engineering, University of Bologna, 47121 Forlì, Italy; jessica.rossi12@unibo.it \\ 3 Department of Civil, Chemical, Environmental, and Materials Engineering, University of Bologna, \\ 40126 Bologna, Italy; fabio.fava@unibo.it \\ 4 Business Department, University of Brasília, Brasília 70910-900, Brazil; pguarnieri@unb.br \\ * Correspondence: augusto.bianchini@unibo.it; Tel.: +39-0543-374438
}

\section{check for}

updates

Citation: Sani, D.; Picone, S.; Bianchini, A.; Fava, F.; Guarnieri, P.; Rossi, J. An Overview of the

Transition to a Circular Economy in Emilia-Romagna Region, Italy Considering Technological, Legal-Regulatory and Financial Points of View: A Case Study. Sustainability 2021, 13, 596. https://doi.org/10.3390/su13020596

Received: 9 November 2020

Accepted: 6 January 2021

Published: 10 January 2021

Publisher's Note: MDPI stays neutral with regard to jurisdictional clai$\mathrm{ms}$ in published maps and institutional affiliations.

Copyright: $\odot 2021$ by the authors. Licensee MDPI, Basel, Switzerland. This article is an open access article distributed under the terms and conditions of the Creative Commons Attribution (CC BY) license (https:// creativecommons.org/licenses/by/ $4.0 /)$.

\begin{abstract}
The circular economy is a growing and strategic topic and has motivated changes and innovations in several segments of research, businesses, financial sectors and public administration. In this context, the Emilia-Romagna Region (Italy) is considered a pioneer in Italy, due to the efforts taken for the transition towards a circular economy. It was the first Italian region to launch a specific law on the subject besides to have relevant projects. Thus, the objective of this paper is to analyse the efforts aimed at the transition to a circular economy in the Emilia-Romagna Region, Italy, considering technological, legal-regulatory, and financial points of view under a market orientation. Complementary, we pointed out the main initiatives related to the circular economy and the areas of interest. To gather data, we conducted applied, descriptive and qualitative research. The data collection was based on documental analysis, and also considering the results of previous questionnaires and interviews. In addition, we applied a dedicated questionnaire and we consider the outcomes of the project Reinwaste-Remanufacture the food supply chain by testing Innovative solutions for zero inorganic waste. The unit of analysis was the project conducted by ART-ER, entitled "Accelerare la transizione verso l'economia circolare in Emilia-Romagna: Uno studio sullo stato dell'arte, le competenze e $i$ bisogni tecnologici e finanziari". This paper can be useful for researchers and practitioners acting in this field, which can use the results based on public and private policies, investment decisions and further studies.
\end{abstract}

Keywords: circular economy; Emilia-Romagna region; financial aspect; legal-regulatory aspects; market orientation; sustainability; technological aspects; transition

\section{Introduction}

The Circular Economy $(\mathrm{CE})$ is a rapidly growing transversal strategic theme that is stimulating innovation not only in research and businesses but also, in the financial sectors (sustainable finance) and public administration. This fact is motivated mainly because of the growing sensitivity and ethics of sustainability issues (environment, climate, resources, new generations, society) and this in both the abiotic and the biological resource domains.

Several studies related to CE have been published, mainly in the last decade [1-3]. Some studies approach the redesign of production processes in collaboration with suppliers to enable the CE [4]. Other authors conducted studies linking the CE to waste management and reverse logistics in the level of countries, regions or municipalities [5,6]. Some discuss the barriers related to the transition to a CE [7-9]. Additionally, others describe a CE's progress in countries, sectors and firms [10-12]. More recently, some models related to the CE measurement through key performance indicators, covering the environmental, social and economic dimensions were proposed $[13,14]$. 
Although many studies are related to the $\mathrm{CE}$, mostly in the previous years, these studies lack theoretical consistency [3]. It is evident that an alignment with national strategies and cooperation of stakeholders at all levels will be necessary-EU, national, regional and local, considering the European Green Deal, the EU Bioeconomy strategy and the EU Circular Economy Action Plan [15-17]. At the same time, studies at the regional level remain underexplored in terms of market orientation and discussions concerning the opportunities and challenges presented by circularity in the exploitation of local specificities and the environmental and economic regeneration of rural, coastal and former industrial areas [17].

In this context, the $\mathrm{CE}$ is considered strategic for the Emilia-Romagna Region, which was the first to launch an ad-hoc law, identifying the technological, regulatory and financial trends, as well the barriers that will characterise the coming years related to the transition to a circular and more sustainable model. The main Research Questions (RQs) of this study are:

RQ1: Which are the existing financial instruments in the region?

RQ2: Which are the technical-scientific skills in the region?

RQ3: Which are the productive sectors in the Emilia-Romagna Region, their needs and opportunities?

RQ4: Which existing initiatives facilitated the transition, in terms of market orientation in the region?

RQ5: Which are the areas of interest for future initiatives?

Based on these research questions, this paper's main objective is to analyse the efforts aimed at the transition to a CE in the Emilia-Romagna Region, Italy, considering barriers, technological, legal-regulatory, and financial points of view under a market orientation. Complementary, we also pointed out the main initiatives related to the $\mathrm{CE}$ and the areas of interest of the Emilia-Romagna Region. It is essential to point out that the market orientation considered in this paper is concerned with the ability of companies, academia and local Government to adapt to the new demands of the market. This adaptation towards a CE point of view is aimed to develop/adopt new industrial processes, new products, new business models, sectors with the potential to be exploited and, new technical skills required for it. It is possible to use other orientations in studies related to $\mathrm{CE}$, such as political and territorial ones, but this paper does not have the purpose of discussing these issues.

To reach this objective, we conducted applied, descriptive and qualitative research. The data collection was based on documental analysis, also considering previous questionnaires and interviews, and a dedicated questionnaire sent to some Italian universities, national research recentres and private companies in the Rete Alta Tecnologia (High Technology Network). The unit of analysis was the project conducted by ART-ER, entitled "Accelerare la transizione verso l'economia circolare in Emilia-Romagna: Uno studio sullo stato dell'arte, le competenze e i bisogni tecnologici e finanziari", and the results from the project Reinwaste-Remanufacture the food supply chain by testing Innovative solutions for zero inorganic waste (https:/ / reinwaste.interreg-med.eu/). "Reinwaste, financed by the European Regional Development Fund of the European Commission through INTERREG MED Programme, contributes to the reduction of inorganic waste production, favouring the adoption of greener and circular solutions by agriculture and food industry, with a focus on SMEs." The project had the main goal to investigate the skills available, the strategic objectives, the transition processes underway, the enhancement of the current, and the obstacles and development opportunities that the area perceives. Identifying these elements and their analysis will help define future strategies and innovation policies with repercussions on economic and social development in a circular and sustainable perspective in the Emilia-Romagna Region. The approach used in this project can serve as a "best practice" to other Italian Regions interested in accelerating the transition towards a CE to be in line with the European directives and Italian positioning. 
As the main results of these studies, we can point out the synthesis of the regulatory overview related to the CE at European, Italian and Regional (Emilia-Romagna) levels, besides describing the leading financial and technical-scientific instruments dedicated to CE. A particular focus on the Emilia-Romagna is the interconnection among the two studies: the needs of the Emilia-Romagna region's productive sectors, referring in particular to agriculture and food and textile industries. Finally, we identified the main initiatives and areas of interest related to the studied region's economy.

In terms of contributions, this paper can be useful for researchers and practitioners acting in this field, which can use the results based on public and private policies, investment decisions and further studies.

This paper is structured as follows: Section 1 presents the contextualisation, research gap, main objective and main results found in the study. Section 2 offers the literature review supporting the study, related to the $\mathrm{CE}$, the main related barriers, the orientations of studies related to the CE transition and, the regulatory and legal issues involved in this context. Section 3 describes the methodological procedures to conduct the research and explains how we analyse the results. Section 4 presents the results found, discussing it in light of theory. Finally, Section 5 delivers the concluding remarks.

\section{Literature Review}

\subsection{Circular Economy}

Terms such as Sustainable Development and Sustainability became part of public policies and, consequently, entered into the business management process and the whole of society [18]. Thus, a paradigm shift is urgent to replace the idea of the current production model and consumption based on unlimited consumption of raw material and energy [19].

The CE is recognised worldwide as a new way of doing business based on the coordination of the entire supply chain, considering the direct and reverse flows enabling the reduction of resources and the negative impact on the environment [6]. CE has as the primary purpose to change the linear mindset of "taking, making and disposing of", to a circular in which "reduce, reuse, repair and recycle" are principles to be respected [20].

The CE's main purpose is to maintain products and materials in circulation for as long as possible; to increase the use of waste and reduce the use of raw or primary resources. Besides that, when a product reaches the end of its life, its reuse is motivated to create more value in the economy with less extraction of natural resources levels $[18,21]$.

Thus, it is evident that the transition towards a $\mathrm{CE}$ will require changes in behaviours, organisational culture, business models, priorities and policies. Additionally, it is crucial to consider that the transition will require efforts at the macro-level (city, province, region or country), meso-level (industrial symbiosis, industrial eco-parks) and micro-level (organisations, products, consumers, citizens). Regarding the macro level, it involves policy changes at the national, regional and municipal levels $[17,18,21,22]$.

This new concept can provide different actions for implementing strategies aimed at sustainability, such as (i) change in social and economic dynamics at the macro and administrative level [23]; (ii) support from companies in the implementation of circular processes to disseminate new forms of consumption and product design; and, (iii) discussion of industrial symbiosis experiences [24].

Undoubtedly, the $\mathrm{CE}$ has been receiving more and more attention in several countries. However, it is still being found in the initial stages to achieve a better balance and harmony, in the Economy, Environment and Society [19]. However, in many countries, the implementation of $\mathrm{CE}$ still focuses on recycling instead of reuse, presenting promising and attractive perspectives for (i) new models of circular production and consumption [19]; (ii) future research [3,19]; and (iii) development of policies to encourage its adoption and practices [3]. 
Considering a vision based on the CE principles, the system should maintain the value of products, materials and resources for as long as possible. Additionally, it should minimise waste generation, aim to develop a sustainable economy, release few emissions of dioxide carbon, use resources efficiently and remain competitive [25].

The EU Green Deal [15] and the New EU CE Action Plan [16] establish that the transition towards a CE will be systemic, profound, disruptive and transformative, in the $\mathrm{EU}$ and beyond [16]. It will require an alignment and cooperation of all stakeholders at all levels-EU, national, regional and local, and international [17,18,21].

European Union Member States have been pushing ahead the transition to a CE model, with the implementation of a set of measures popularised as the "CE Package" brought several managerial challenges to European countries, states and municipalities. Besides that, more recently, the European Green Deal [16,26].

In this context, Italy has created the Italian CE Stakeholder Platform-ICESP, initiated by Energia Nucleare ed Energia Alternative (ENEA), mirroring the European initiative (ECESP) to enable initiatives, experiences, the discussion of critical issues and perspectives and to promote specific dedicated actions related to the transition towards a CE [27]. The Italian Government announced the setup of a national Bioeconomy Strategy in 2017 (BIT) and, more recently, its update ("A new Bioeconomy strategy for a sustainable Italy", BIT II, 2019) and the related implementation action plan ("Implementation action plan -2020-2025- for the Italian bioeconomy strategy BIT II, 2020) addressed to translate some emerging BIT II priorities into distinct actions and related monitoring, to ensure an operational roll-out of the Italian circular Bioeconomy potential across Italy in the next five years [28].

The CE is a rapidly growing, transversal and strategic theme that is stimulating innovation not only in research and businesses but also in the financial sectors (sustainable finance) and the public administration. The growing sensitivity and ethics of sustainability issues (environment, climate, resources, new generations, society) have motivated the CE [29].

\subsection{Studies on the Transition towards a Circular Economy}

Although many studies are dealing with CE concepts, mainly published in last years, the literature on the $\mathrm{CE}$ is mostly concentrated on the industrial and technology-driven changes than the transition towards the $\mathrm{CE}$ in cities or regions [30,31]. In this context, we can highlight some examples, such as the studies from [17,31,32]. However, it is essential to point out that our intention in this paper, is not to exhaust the discussion on the topic of transition towards a CE. We understand that there are many ideas, approaches, and dimensions, and the orientation of the discussion will depend on the field of acting and the points of view considered in the studies.

In this context, as mentioned, studies related to the transition towards a CE can have different approaches, the political, the market and the territorial orientation can be considered as a lens of analysis [31,33,34]. For this paper, we used the transition in terms of market orientation in the Emilia-Romagna Region, Italy.

The transition towards a CE requires a systemic change and, in this context, regions play an essential role. Finland's Päijät-Häme region was studied by [17], in which European and national targets were implemented aiming the transition. This region elaborated a roadmap with strategies towards the $\mathrm{CE}$ transition. This roadmap involved the analysis of perceptions of stakeholders from local government, industry, and academia, focusing on closing both technical and biological loops and promoting sustainable energy technologies, new consumption models and demonstration sites. 
The authors of the reference [32] explored the CE imaginaries in the European cities of Amsterdam, Paris and London, analysing how it can support transformative pathways for socially inclusive and environmentally desirable value creation in cities. The authors stated that the enhancement of circularity in urban systems management and resource flows could spotentialise the change in the production and consumption-related patterns.

The study of reference [31] analysed the CE's strategies and practices in Brussels, interviewing key regional stakeholders (Bruxelles Economie et Emploi, Hub, Bruxelles-Environnement), involved in the formulation of Regional Programme for CE (PREC-Programme Régional en Economie Circulaire). The focus of this study was on the urban political economy of the CE.

The discussion related to the demand for governance practices and business models related to the $\mathrm{CE}$ is a growing-topic, considering that it is essential to enable changes in urban lifestyles and consumption habits and patterns. However, at the same time, we cannot ignore that the urban population increasing is a cause of a series of environmental challenges, such as resource scarcity, pollution, and ageing infrastructures [32]. Complementary, the transition management should cover a governance approach centering on public-private bodies to give voice to the groups of stakeholders involved in this process [33].

Some authors [30] consider that CE studies tend to be dominated by a businessfocused narrative related to the acquisition of competitive advantage than a broader urban sustainability agenda. In this context, the authors conducted a study with six European case studies, trying to discuss circular cities' issues under the perspective of urban sustainability [30].

The authors of reference [34] analysed how the urban landscape design potentialises the social and economic dimensions based on urban metabolism, considering the case of the Belgian Central Limburg region's transition into a CE. According to this study, the areas covered by urban metabolism should be planning, landscape architecture and engineering. Besides, the analysis had a focus on how the exploitation of a landscape-based territorial reading can induce alternative future urban metabolisms. Additionally, [35] proposed the concept of urban circularity and introduces an analytical framework based on the circularity concepts on design and planning.

Another study [31] addressed the political-economic concerns related to the transition of urban economies towards a circular paradigm, considering the lens of political-economic theory to develop a scale perspective on the CE. The authors exploited the complex relationships between the urban and the CE. The authors' main issue is associated with the promise of a fundamental re-territorialisation of production, distribution, consumption, waste management, and innovation, which has conflicting objectives considering the current extractivist system of accumulation on their territory.

\subsection{Barriers to Transition towards a Circular Economy}

Barriers can be elements that make it impossible for organisations to embark on environmental initiatives [36]. Some authors agree that several possible interaction effects are among the several categories of barriers [8,37]. As an illustration of this issue, we point out that " ... if there is a "Lack of data of impacts", for example, market actors may have limited interest in implementing CE business models, thus encouraging the persistence of 'Limited funding for circular business models' and low pressure to remove 'Obstructing laws and regulations' ... " [8]. The study about barriers to implementing and transitioning towards a CE is a topic of great interest in literature. We point out some of these studies here, however, our intention was not to exhaust the literature on barriers.

Some authors categorise the barriers into eight main groups [7,8]: (i) Cultural Lacking: consumer interest and awareness, hesitant company culture, operating in a linear system, limited willingness to collaborate in the value chain; (ii) Attitudinal: sustainability perception, risk aversion; (iii) Market: low virgin material prices, high upfront investment costs, limited funding for circular business models, limited standardisation; (iv) Regulatory: obstructing laws and regulations, lack of global consensus, limited circular procurement; (v) Technological: narrow circular design; too few large-scale demonstration projects; lack 
of data, e.g., on impacts, ability to deliver a high quality remanufactured product; (vi) Financial: measurement of financial benefits of CE, financial profitability; (vii) Structural: lack of exchange of information, unclear distribution of responsibilities, and (viii) Operational: infrastructure management/supply chain.

The cultural barriers, such as consumer interest and awareness, and hesitant business culture, are the main barriers to $\mathrm{CE}$, followed by market barriers and lack of synergistic government interventions to accelerate the transition to a $\mathrm{CE}$, as the absence of support policies [8]. Similarly, [9] states that political and institutional barriers to implementing the $\mathrm{CE}$ as the main obstacles to an effective transition. It is essential to understand the complexities that countries in transition need to face to elaborate strategies and plans to overcome them.

Complementary, a study [37] categorised the barriers in "Harder" factors, covering 'Technical related barriers': inappropriate technology, the lag between design and diffusion, lack of technical support and training; "Economic/Financial/Market related barriers": Large capital requirements, significant transaction costs, high initial costs, asymmetric information, uncertain return and profit and, "Softer" factors, covering 'Institutional/Regulatory/Social/Cultural': Misaligned incentives, lacking a conducive legal system, deficient institutional framework, Rigidity of consumer behaviours and businesses routines.

\subsection{Legal-Regulatory Instruments at European, National and Regional Levels}

At the European regulatory level, the tools identified to launch a circular economic model, to date, are the four directives of the European Union, making up the CE Package, which entered into force on 4 July 2018 and published in the Official Journal of the European Union of 14 June 2018 [38]. At the Italian regulatory level, the legislative framework for the $C E$ is composed of a stratification of several and different documents produced over the years, of which the paper "Towards a CE model for Italy", published jointly by the Ministry of the Environment and Protection of the Territory and the Sea [39]. Some data were also found in the reference [40]. The main directives are demonstrated in Table 1.

Table 1. European regulations related to the Circular Economy (CE).

European Regulations

\section{Directive}

Directive (EU) 2018/849 of the European Parliament and the Council, of May 30th 2018, modifies the 2000/53/EC directives relating to end-of-life vehicles, 2006/66/EC related to batteries and accumulators and to waste batteries and accumulators e 2012/19/EU on waste electrical and electronic equipment [41]. Directive (EU) 2018/850 of the European Parliament and the Council of May 30th 2018, amends Directive 1999/31/EC on the waste landfill [42].

Directive (EU) 2018/851 of the European Parliament and the Council, of May 30th 2018, amends Directive 2008/98/EC on waste [43].

Directive (EU) 2018/852 of the European Parliament and the Council of May 30th 2018, amends Directive 94/62/EC on packaging and packaging waste [44].

\section{Measures}

(i) the introduction of a rapid monitoring system for compliance with the objectives;

(ii) extended responsibility for producers, with the definition of minimum requirements differentiation of the contribution due based on the costs necessary for the treatment of products at the end of their life;

(iii) the promotion of prevention (including food waste) and reuse;

(iv) the regulation of by-products and end-of-waste, which may not be considered as waste as long as they meet certain conditions;

(v) the alignment of definitions, calculation methods for objectives, reporting obligations and implementing provisions.

Table 2 presents the Italian regulations related to the $\mathrm{CE}$ and the main measures comprised. 
Table 2. Italian regulations related to CE.

\begin{tabular}{|c|c|}
\hline \multicolumn{2}{|r|}{ Italian Regulations } \\
\hline Directive & Measures \\
\hline $\begin{array}{l}\text { Towards a Circular Economy model for Italy: } \\
\text { Strategic framework and positioning document. } \\
\text { Ministry of the Environment and Protection of } \\
\text { Territory and Sea, and the Ministry of } \\
\text { Economic Development [39]. } \\
\text { Law no. } 221 \text { of } 28 \text { December } 2015 \text {. This } \\
\text { obligation was subsequently also introduced in } \\
\text { the "Procurement Code" (Legislative Decree } \\
50 / 2016 \text { amended by Legislative Decree } \\
56 / 2017 \text { ) in art. 34, bearing "Criteria for energy } \\
\text { and environmental sustainability" [45] }\end{array}$ & $\begin{array}{l}\text { (i) a more straightforward and more understandable legislative framework; } \\
\text { (ii) financial incentives for sustainable production and consumption; } \\
\text { (iii) communication and information activities to spread culture on the CE; } \\
\text { (iv) promotion of research and innovation. }\end{array}$ \\
\hline
\end{tabular}

Source: $[39,45]$.

Table 3 shows the principal Emilia-Romagna Region's principal regulations, which was a pioneer due to the ratification of the first law in Italy related to the circular economy.

Table 3. Regional (Emilia-Romagna) regulations related to CE.

\begin{tabular}{|c|c|c|}
\hline \multicolumn{3}{|c|}{ Regional Regulations } \\
\hline Directive & & Measures \\
\hline $\begin{array}{l}\text { Regional Law n. } 16 \text { of } 5 \text { October 2015. Provisions in } \\
\text { support of the Circular Economic, the reduction of } \\
\text { urban waste production, reuse of end-of-life goods, } \\
\text { separate collection and amendments to the regional } \\
\text { law } 19 \text { August } 1996 \mathrm{n} \text {. } 31 \text { (discipline of the special tax } \\
\text { for landfilling of solid waste) [46]. }\end{array}$ & $\begin{array}{l}\text { (i) } \\
\text { (ii) } \\
\text { (iii) } \\
\text { (iv) } \\
\text { (v) } \\
\text { (vi) } \\
\text { (vii) }\end{array}$ & $\begin{array}{l}\text { more sustainable waste management; } \\
\text { more information to create a new civic awareness; } \\
\text { new financial instruments (both for the public administration and } \\
\text { for businesses) } \\
\text { reduction of per capita waste production by } 20-25 \% \text { by } 2020 \text {; } \\
\text { waste collection of } 73 \% \text { by } 2020 \text {; } \\
70 \% \text { recycling by } 2020 \text { ( } 65 \% \text { of municipal waste by } 2030 \text { for the EU); } \\
\text { landfill less than } 5 \% \text { by } 2020 \text { ( } 10 \% \text { by } 2030 \text { for the EU). }\end{array}$ \\
\hline $\begin{array}{l}\text { Regional Waste Plan, approved } \\
\text { On } 3 \text { May } 2016 \text { [47] }\end{array}$ & $\begin{array}{l}\text { (i) } \\
\text { (ii) } \\
\text { (iii) } \\
\text { (iv) }\end{array}$ & $\begin{array}{l}\text { activation of a Pay-As-You-Throw system by 2020; } \\
\text { activation of public-private partnerships for the prevention and } \\
\text { recovery of waste in various economic sectors; } \\
\text { opening of an incentive fund for virtuous municipalities of } 11.5 \\
\text { million Euro per year; } \\
\text { activation of permanent working groups for by-products with the } \\
\text { production of an official regional register of by-products (peach } \\
\text { stones; kernels of apricot; salt from the salting of the meat; black } \\
\text { liquor-waste from the paper production process; green residues of } \\
\text { sweet corn; residues of the ceramic industries) in alignment with } \\
\text { the national ones; } \\
\text { information and awareness campaigns also through a permanent } \\
\text { forum on the CE, aligned with the national one. }\end{array}$ \\
\hline
\end{tabular}

Source: [46,47].

European countries are pioneers in achieving sustainable development through a paradigmatic shift: moving from a linear economy to a CE [32,33]. Part of this effort is translated into a set of measures that were conventionally called the "Circular Economy Action Plan" [16,25].

\section{Methodological Procedures}

To contribute to the knowledge process of the $\mathrm{CE}$ and enable the transition from a linear to a $\mathrm{CE}$, we conducted a transversal and interdisciplinary study in collaboration with the actors involved in research and innovation system of the Emilia-Romagna Region, Italy, covering universities, research centres, financial organisations, industries, regional Government, business association and cooperatives among others. 
This study is classified as applied, descriptive and qualitative research. As the study's strategy, we used a case study. The analysis unit is the project conducted by ART-ER, entitled "Accelerare la transizione verso l'economia circolare in Emilia-Romagna: Uno studio sullo stato dell'arte, le competenze e i bisogni tecnologici e finanziari" [29], in English, "Accelerating the transition to the Circular Economy in Emilia-Romagna: A study on the state of the art, skills and technological and financial needs". Conducted in 2019 and published in 2020, coordinated by ART-ER S.Cons.p.A (Attrattività Ricerca Territorio), the consortium of Emilia-Romagna Region, promotes the region's growth through the development of innovation and knowledge, the attractiveness and internationalisation of the territory.

This paper aims to describe the main results of this project; the data collection instruments used for this were documental analysis of reports from the European Commission and direct observation. For the documental analysis, a model proposed by the European Commission (Research and Innovation) in work carried out by "Informal commission expert group on support to Circular Economy financing" published in March 2019, and we considered the report "Accelerating the transition to Circular Economy" recommendations. The report from Osservatorio Green Economy in Emilia-Romagna, in English The green economy in Emilia-Romagna Region [40].

In addition to the documental analysis, we conducted the data collection through a dedicated questionnaire, sent to some Emilia Romagna universities, research recentres and private companies in the Rete Alta Tecnologia" (High Technology Network). We considered the criteria of representativeness and accessibility to define the sample of participants, which means that we choose the respondents considering the information they possess, their expertise in the CE field, and the contribution to the study's objective, besides the availability to participate. The participants invited to respond to the survey were 10, and the entire sample provided the answers, all useful for analysing results. The questionnaire was applied online through google forms. We divided the questionnaire into three parts: (i) in the first part, there are 20 general questions; (ii) the second part consisted of 25 specific questions; and (iii) the third part had a variable number of questions, with a deeper level of specificity, determined by the respondents' single choices among the sectors available in the second part. We based the questions, and the semi-structured script on the primary variables of the study, which were: (i) barriers to the transition of CE in the Emilia-Romagna Region; (ii) financial instruments; (iii) technical-scientific skills; (iv) production system needs and, (v) existing initiatives and (vi) areas of interest. As anticipated, we investigated deeply all these topics for several sectors.

To analyse the data collected, we used descriptive statistics, considering the frequency of answers for the questionnaire and the categorical content analysis to deal with the results of interviews. The main outcomes were the construction and proposition of framework knowledge of the CE in the Emilia-Romagna Region, considering technological, legalregulatory and financial perspectives.

It was a trans/cross-disciplinary team of research work, considering the classification from [48], composed of two main fronts ART-ER and Academia. The former, composed of two people, due to the nature of their daily work with companies from the Emilia-Romagna Region, can be characterised as "reflective scientists". The four academic researchers acted as "facilitators". In this context it is worth noting the limits of the work of researchers, those from the first front have a more active role facing the participants of the study, which enabled the access to them and the agreement to participate in the research. To soften the bias related to the reflective scientists' values and points of view, the Academic researchers performed the facilitation process and the critical analysis, giving support to elaborating instruments of data collection and analysis of the results.

\section{Presentation and Discussion of Results}

In the first part of the results, we analysed the CE's general framework through a documental analysis, starting from a variety of topics related to the $\mathrm{CE}$ derived from the Circular Economy Action Plan of the European Commission [16]. The analysis of 
documents aimed not only at the recognition of skills and needs (through direct surveys) and the analysis of the regulatory and financial framework, all aspects related to transition processes both in favour of and against it (obstacles or enablers).

Subsequently, the Emilia-Romagna context was analysed, mapping ongoing experiences in terms of research and innovation initiatives and education, and identifying essential points on which to intervene and/or envisage new projects. For the enhancement of the existing initiatives, the phenomenon was analysed, on effects on competitive positioning and on the obstacles encountered both from the point from a regulatory and financial point of view to then offer the possibility of future development, expansion of markets, new research and investment paths and economic growth territories in a sustainable way.

\subsection{Financial Instruments at European and National Levels}

There is an essential part of the CE's transition to the financial resources and tools that can make this path possible. The Ellen MacArthur Foundation [49] has estimated that the complete transition to the CE by 2030 would lead to Europe: (i) a 7\% increase in GDP; (ii) a reduction in annual $\mathrm{CO} 2$ emissions of $17 \%$; (iii) a $10 \%$ decrease in natural resources used in industrial processes; (iv) will offer investment opportunities for 320 billion euros by 2025 .

In the European level, the European Commission $[15,16]$ has estimated that the adoption of solutions consistent with the concept of circularity will reduce greenhouse gas emissions by $2-4 \%$ and that the recycling and reuse of resources, waste reduction, ecosustainability of production processes, together with other measures related to the $\mathrm{CE}$ could allow European companies to save 600 billion euros each year, equal to $8 \%$ of turnover. The European Commission offers a wide range of financial instruments to support the $\mathrm{CE}$ and the efficiency of the use of resources, many of which are also confirmed in the next programming; between these: LIFE+; Horizon 2020; Public-private partnerships FoF (Factories of the Future); SPIRE (Sustainable Process Industries through Resource and Energy Efficiency); BBIJU (Bio-based Industries Joint Undertaking); Community of Innovation of the European Institute of Technology: Raw Materials, Climate, Food, Manufacturing and, Mobility and, the new Horizon Europe framework program.

The European Parliament, the Member States and the Commission have approved a preliminary agreement in partnership with the European Investment Bank (EIB), with the new Community program called InvestEU. The InvestEU program provides the unification of the European Fund for Strategic Investments (EIF) and 13 other EU financial instruments that currently support investments in the Union in a single program. These instruments aim to stimulate investments of a public and private nature within the European Union in the period 2021-2027, in critical sectors such as Artificial Intelligence, the CE, Action for the Climate and Social Inclusion. Simplification is among the program's objectives and the rationalisation of investment support through the preparation of a system of uniform rules and procedures [29]. Italian companies and Government can apply for the calls and submit proposals, whether they meet the requirements, to obtain resources to make strategic investments related to Artificial Intelligence, CE, Climate changes and Social Inclusion.

Therefore, the EIB proposes to be a leading partner in the transition to the $\mathrm{CE}$ and has already made available in recent years EUR 2.4 billion in the form of co-financing. Still, the CE's lending needs and potential are much broader: the full implementation of the current reliable waste directives-whose recycling and waste recovery targets waste are in line with a CE—it alone would require higher investments to 40 billion euros by 2020 [29]. 
The range of instruments offered by the EIB is very broad: (i) InnovFin; (ii) InnovFin Thematic Investment Platforms; (iii) InnovFin Emerging Innovators; (iv) InnovFin Science; (v) InnovFin Energy Demo project; (vi) InnovFin MidCap Growth Finance; (vii) InnovFin SME Guarantee Facility; (viii) European Fund for Strategic Investments; (ix) European Investment Advisory Hub; (x) InnovFin Advisory; (xi) Green Bond [29]. The member countries of the EU can access these instruments, then Italy is also eligible.

The EIB also offers support in assessing whether a CE project is eligible for its financial instruments and which one loan approach and mechanism is more appropriate.

In terms of Italian financial instruments, the National Industry 4.0 Plan adopted by the Government represents a concrete opportunity to spread eco-innovation by strengthening Italian companies' competitiveness. The envisaged measures include those that impact the transition to the $\mathrm{CE}$ where the economic and social components are mentioned directly in the plan itself. It is decided to give equal dignity and value to the environmental protection component, protect natural resources, and enhance the territory. Among the instruments identified by the National Industry 4.0 Plan, some of a financial nature, aimed at supporting the transition phase between research and development in eco-innovation and eco-design.

\subsection{Technical-Scientific Skills at a Regional Level}

In Emilia-Romagna, there is a dynamic interaction between academia and industry, which has been consolidated for at least a decade thanks to the regional initiative to build a network of collaboration: Rete Alta Tecnologia (High Technology Network). The Rete Alta Tecnologia (https:/ / www.retealtatecnologia.it/en) provides expertise, tools and resources for business development and includes Industrial Research Laboratories and Innovation Centers, located in the Tecnopoli, which is present in the area.

More recently, the network of Clust-ERs has been added to the innovation ecosystem, i.e., communities of public and private entities that share ideas, skills, tools, and resources to support the competitiveness of the most pertinent production systems Emilia-Romagna. The presence of the CE in the region is then illustrated by showing how: (i) regional stakeholders present research infrastructures, design skills, patents and spin-offs related to the theme of the $\mathrm{CE}$; (ii) the regional smart specialisation strategy has contributed to the implementation of projects with an impact on CE issues.

The actors involved in the detection of skills were: Alma Mater Studiorum-University of Bologna; (ii) CNR-National Research Council; (iii) ENEA-National Agency for New Technologies, Energy and Sustainable Economic Development; (iv) Network Laboratories HTN and Clust-ER Greentech and Agro; (v) Politecnico di Milano-Piacenza office; (vi) Catholic University; (vii) the University of Ferrara; (viii) the University of Modena and Reggio Emilia and, (ix) University of Parma.

The perimeter of the skills mapped refers to the entire life cycle of the product. It ranges from design, to process technologies to the evaluation methodologies of environmental impacts and the valorisation of waste and by-products. The perimeter proposed for the survey is in line with the European Commission's CE categorisation system and fully reproduces all the main categories:

(i) Design and eco-design for resource efficiency, repair, disassembly, recycling;

(ii) Manufacturing and de-manufacturing;

(iii) Distribution and consumption (sharing economy, Procurement);

(iv) Reuse, maintenance and re-manufacturing;

(v) Recycling and recovery (waste, water and energy recovery);

(vi) Waste management and valorisation.

As can be visualised in Figure 1. 


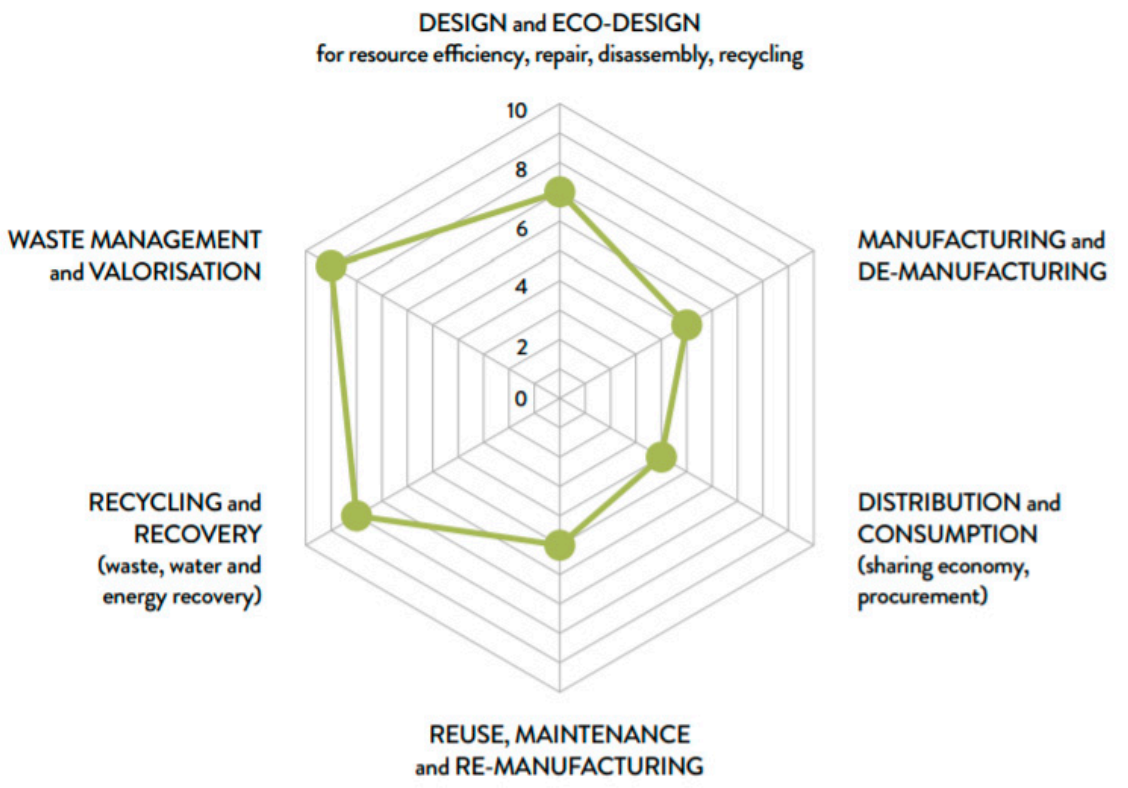

Figure 1. Distribution of regional skills in the areas of the CE. Source: Data from [29].

The regional training offer on the CE issues is vast, as appears from Figure 2. Over 100degree courses are active, with a predominance of the areas related to design and ecodesign and distribution and consumption, and more than half of the regional training offer is international. To date, there are fewer in first and second level Masters, and other courses (for example summer schools) offered. The university training offer in the Emilia-Romagna Region on circular economic issues has significant overall numbers, as shown in Figure 2.

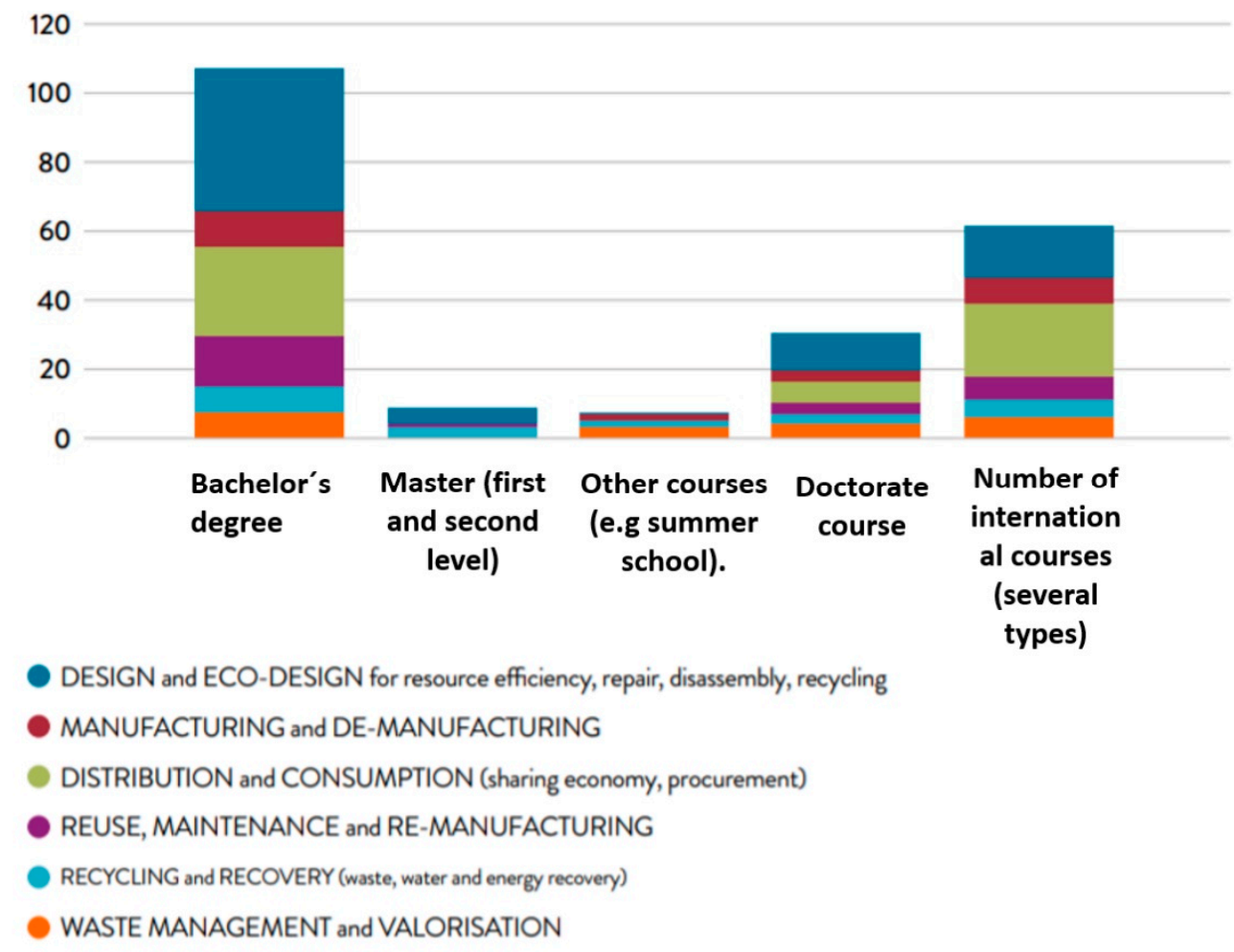

Figure 2. Regional training offer in Emilia-Romagna on the themes of the CE. Source: Data from the reference [29]. 
Regarding the infrastructure (dedicated laboratories and research groups), 70 infrastructures are dedicated to research and innovation on issues of the $C E$ in the region. The numerosity reflects the general distribution skills and therefore sees greater representativeness in the areas of design, ecodesign, recycling, recovery and waste management and valorisation (Figure 3). Among dedicated infrastructures is the CERCIS, centre for research on the CE, innovation and SMEs (Small-Medium Enterprises) of the University of Ferrara. Figure 3 shows the dedicated laboratories in the Emilia-Romagna Region.

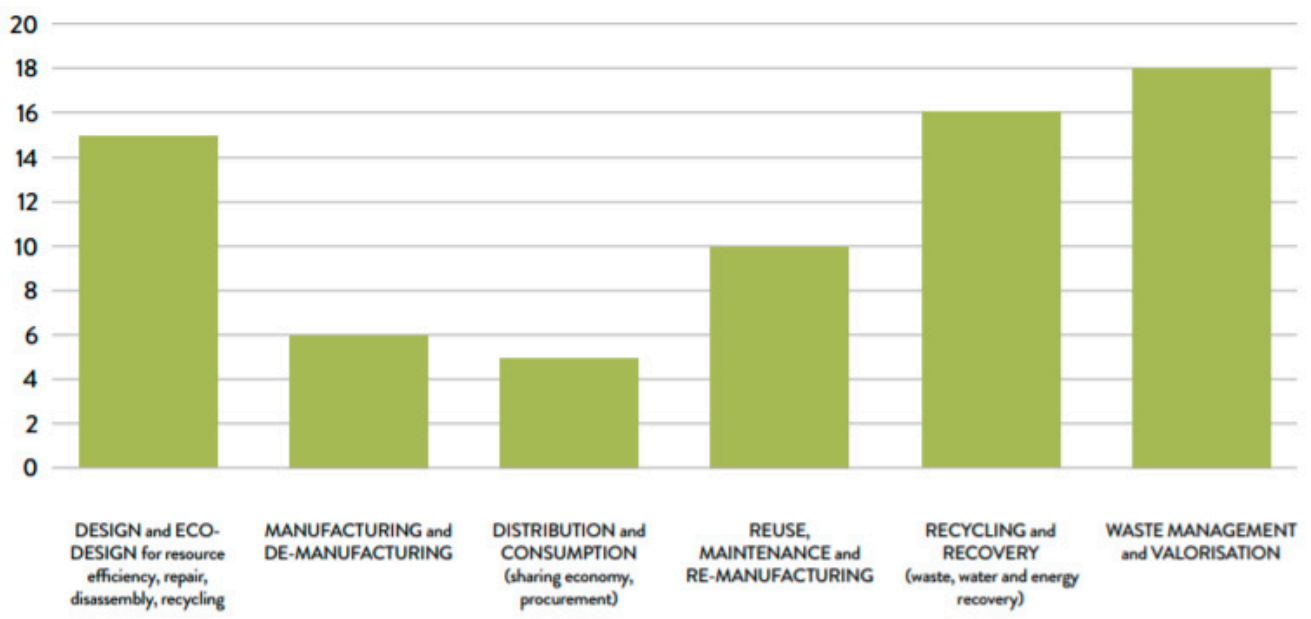

Figure 3. Laboratories dedicated to research topics relating to the CE in Emilia-Romagna. Source: Data from reference [29].

In the three years 2016-2019, were activated in Emilia-Romagna beyond 430 research and innovation initiatives on issues related to the CE (Figure 4), considering European, Italian, and Regional projects and direct collaboration with companies. They are almost equally distributed among co-financed European, national and regional projects (202) and direct collaborations with companies (228), for a total value of over 67 million Euros.

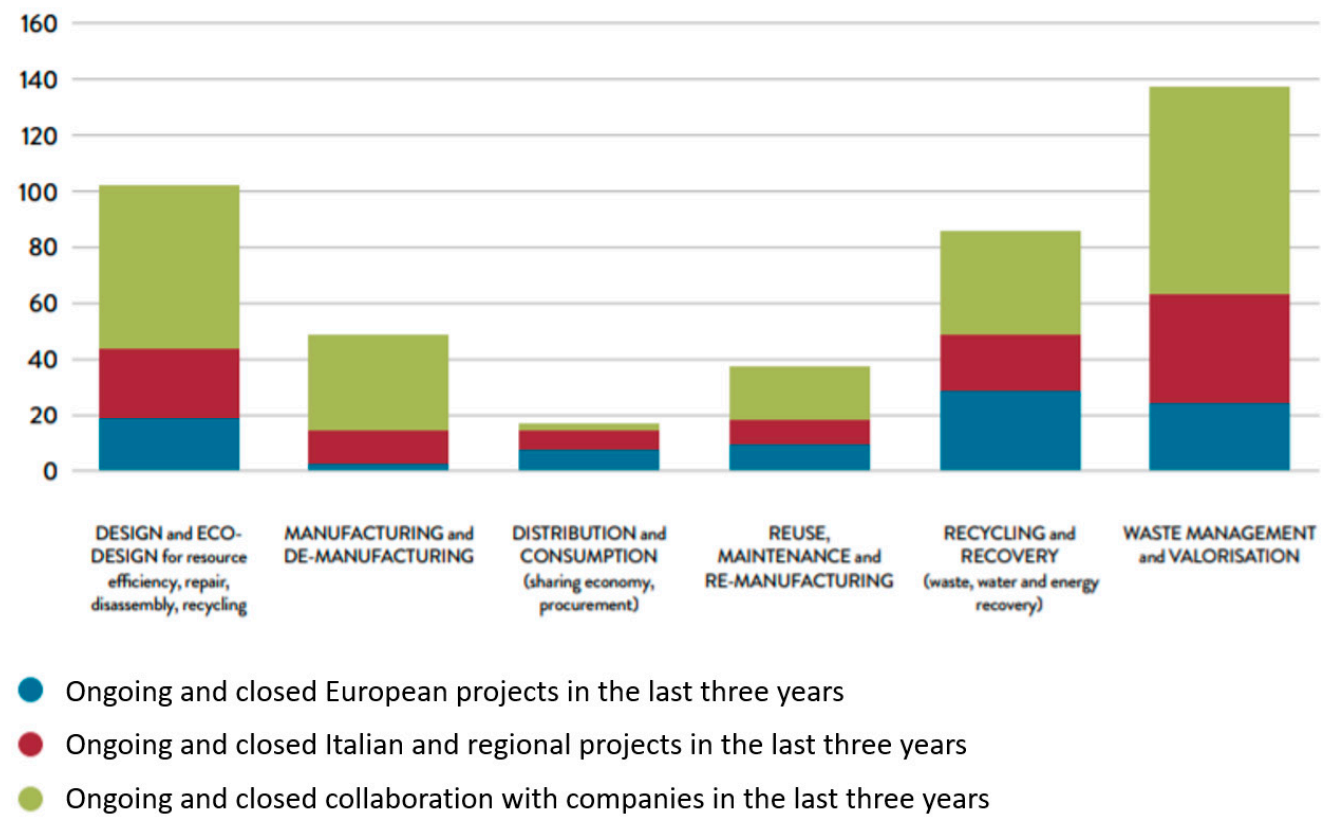

Figure 4. Number of active projects in the period 2016-2019 on the CE's themes in Emilia-Romagna. Source: Data from reference [29]. 
Again, the design capacity reflects the distribution of skills, with a prevalence of projects that address recycling, recovery and valorisation. As for enhancing research activity, patents prevail as a typology compared to the creation of startups or spin-offs. From mapping, we detected a total of 29 patents mainly relating to technologies for recycling and recovery.

\subsection{Production System Needs at a Regional Level}

A first overview, of a general level, is made possible by the answers provided by a sample of 2000 Emilia-Romagna companies, as part of an existing survey conducted in 2018 on the subject of the green economy [40]. Although we cannot make the CE coincide precisely with the green economy, it can be accounted for as a relevant subset. Many considerations made by companies on a more general level can also be considered valid in the subset. In particular, the answers related to the question of the main factors external to the company capable of boosting investments are useful for classification of needs in the green economy and the internal factors that represent an obstacle. Figure 5 answers the answers relating to the stimuli, divided between green companies and non-green companies. These two categories derive from the definitions that the companies have given of themselves by answering the questionnaire (of the 2000 responding companies, $63 \%$ defined themselves green, recognising themselves in one or more of the definitions proposed by the questionnaire administered). Figure 5 shows the stimuli that incentivise companies to adopt green economy initiatives.

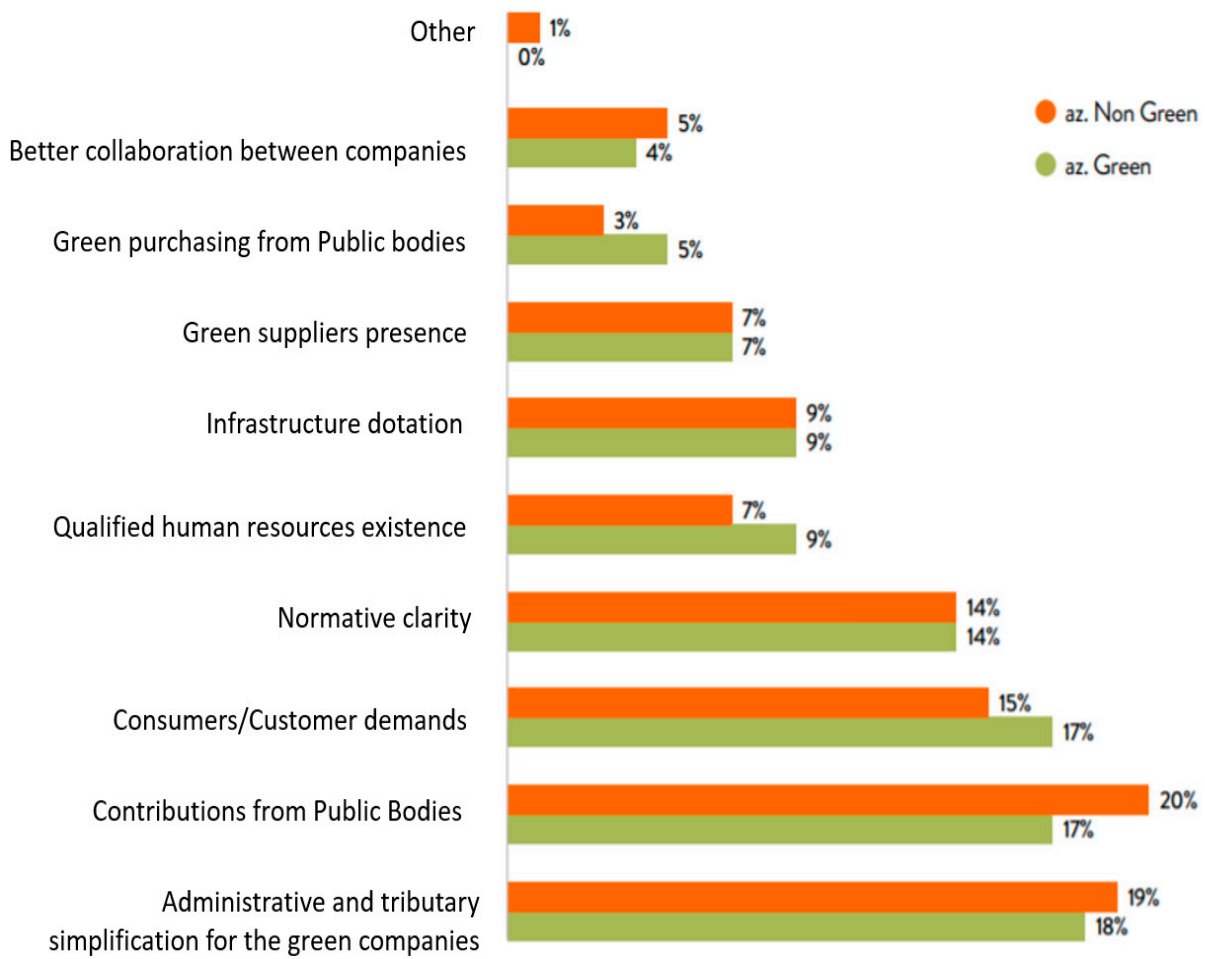

Figure 5. Stimuli that incentivise green and non-green companies to invest in the Green Economy in the Emilia-Romagna Region. Source: Data from reference [40].

A factor considered crucial across the board (both by green companies and non-green with approximately the same percentage of responses) is administrative and tributary simplifications. The fulfilment of bureaucratic obligations is often seen as a burden by companies both in terms of costs and time to devote: a streamlining of procedures or tax concessions are factors that can incentivise investments. Strongly connected to simplifications, is the issue of regulatory clarity. In fact, the regulatory system appears to companies as unclear, fragmented and difficult to interpret and apply (inhomogeneous among sectors 
but also, within the same theme, among territories), if not entirely missing (as in the case of end-of-waste).

Alongside these two factors, relevant for both groups of companies, others emerge highly rated factors but with different percentages between the two groups: green companies see more significant incentives to invest in the environment if there is adequate demand market (requests from customers or end consumers), while the availability of contributions acquires greater weight for non-green companies ( $+3 \%$ compared to green), showing that these are companies with less autonomy and resourcefulness in making green-oriented investments.

The remaining factors all lie below $10 \%$. However, we underline the gap in the response relating to the presence of qualified human resources, to which companies green attribute greater importance than non-green ones $(+2 \%)$ : the companies most inclined and attentive to innovation in the environmental field are not companies that are taking the first steps towards greater environmental sustainability but intend to face more challenging and more radical changes, for which it is necessary to have of specific technical skills. Figure 6 shows the main obstacles to invest in Green Economy initiatives for companies from the Emilia-Romagna Region.

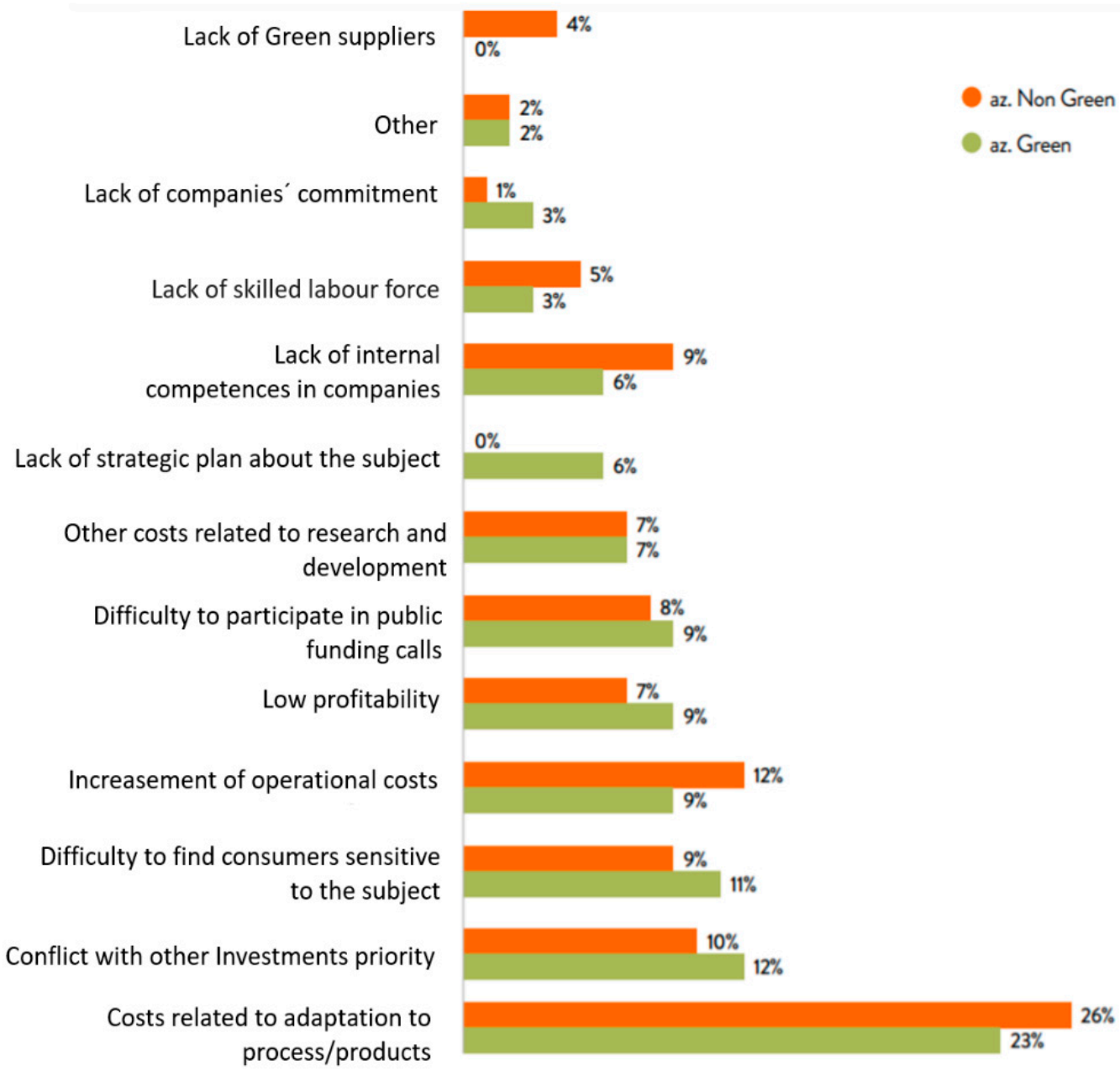

Figure 6. Internal obstacles for making investments in the Green Economy in the Emilia-Romagna Region. Source: Data from reference [40].

About a quarter of the entire sample sees the high costs of management and technological adaptation of processes or products as the main obstacle to greater dissemination of the green economy. Closely related to compliance costs, green companies identify as a further obstacle the fact that environmental investment is not seen as a priority (Conflict with other 
investment priorities 12\%): expenditure for improvement environmental is still seen as subordinate to other investments considered fundamental for the proper functioning of the company.

A possible reading of this data lies in the short- to medium-term horizon with which companies usually plan their activities. An environmental investment can have incompatible payback times with this horizon. Therefore, it would require a corporate vision in which the protection of the environment is pursued regardless of profits and is understood as an element of competitiveness.

Green companies see a further obstacle in the difficulty of finding a market (consumers/customers) sensitive to environmental sustainability issues (11\%): this response further confirms that environmental investment is subordinated to economic sustainability, in this case to a forecast of higher sales and therefore increased revenues.

Companies that do not work in the Green Economy sectors show some obstacles that are of lesser importance for those already working on environmental issues. The increase in operating costs is significant for $12 \%$ of the non-green companies interviewed, compared to $9 \%$ of the greens; for these companies, investing in environmental issues can mean changing their corporate mission, directing it towards eco-compatibility and is therefore perceived as a more significant effort than those already dealing with these issues or work on it daily.

Complementary, to contextualise the production system's needs for the transition towards a CE, we interviewed a small sample of companies in the Emilia-Romagna Region. In this case, the answers do not have a statistical value but allow for highlighting specific needs and merit and offering a substantial convergence on the three factors in Table 4 .

Table 4. Convergence of Productive needs and merit of the Emilia-Romagna Region.

\begin{tabular}{|c|c|c|c|}
\hline & Context Factors & Internal Factors & Networking \\
\hline- & $\begin{array}{l}\text { The cultural change falls into this } \\
\text { category, which includes the } \\
\text { diffusion among consumers of new } \\
\text { consumption patterns, as well as } \\
\text { new awareness on the part of } \\
\text { the institutions; } \\
\text { The regulatory framework is also } \\
\text { included, which must represent all } \\
\text { economic operators a defined } \\
\text { perimeter in which to move with } \\
\text { transparency in the certainty of } \\
\text { the rules. }\end{array}$ & $\begin{array}{l}\text { - New factors are needed within the } \\
\text { company visions and new skills, as } \\
\text { well as new technologies, especially } \\
\text { to improve the recovery of } \\
\text { materials and energy; } \\
\text { The implementation of more } \\
\text { innovative business models such as } \\
\text { remanufacturing; digitalisation } \\
\text { and virtualisation; } \\
\text { The use of innovative technologies } \\
\text { such as Artificial Intelligence (AI) } \\
\text { and the Internet of Things (IoT) can } \\
\text { facilitate the transition. }\end{array}$ & $\begin{array}{l}\text { Networking not only between } \\
\text { companies to share acceptable } \\
\text { practices and knowledge, but also } \\
\text { with the Academy for the } \\
\text { transference of } \\
\text { innovative technologies; } \\
\text { The interdisciplinary nature of the } \\
\text { CE makes collaboration and sharing } \\
\text { strategic and necessary for its } \\
\text { full implementation; } \\
\text { The role of institutions, especially } \\
\text { for the creation of local districts or } \\
\text { supply chains, and the } \\
\text { citizenship/consumers element. }\end{array}$ \\
\hline
\end{tabular}

Source: Research data.

\subsection{Existing Initiatives and Areas of Interest}

\subsubsection{Existing Initiatives Related to CE in the Emilia-Romagna Region}

The 2014-2020 Operational Programme of ERDF, in coherence with the Regional Smart Specialization Strategy finances strategic research and innovation projects to support sustainable development (green and blue economy). Thanks to ERDF Axis 1, 60 million Euros have been invested on issues of great importance for the sustainability of the regional economy in 53 strategic industrial research projects involving a total of 1600 researchers (almost 600 new hires), 222 companies and 218 industrial research laboratories accredited to the Rete Alta Tecnologia (High Technology Network), including 11 industrial research projects directly on the issues of the CE.

Many of these results represent a collection of good practices. They are mapped as part of the national survey implemented by the Italian CE Stakeholder Platform (ICESP), which mirrors the European CE Stakeholder Platform (ECESP). The good practices are 
concrete experiences of relevance for the implementation of a CE. In particular, good CE practices must demonstrate to apply circularity criteria that make it possible to preserve the value of resources during the entire life cycle of a product or process, favouring the closure of cycles. We highlight some of them:

- improving the recyclability of materials or the use of secondary raw materials;

- prevention in the production of waste, its collection and selection to favour its further use;

- $\quad$ extending the life span of a product through reuse, repair and maintenance or redesign;

- $\quad$ smarter use of resources including energy resources in industrial processes;

- the introduction of new consumption models by providing consumers with information on the efficient or alternative use of products;

- the improvement of flows and exchanges of resources and by-products through industrial symbiosis.

To analyse the current application of the $\mathrm{CE}$ in the Emilia-Romagna region, this study identified about 40 different $C E$ initiatives, and in the map, the geographical distribution, the field of application and the reference sector are shown in Figure 7.

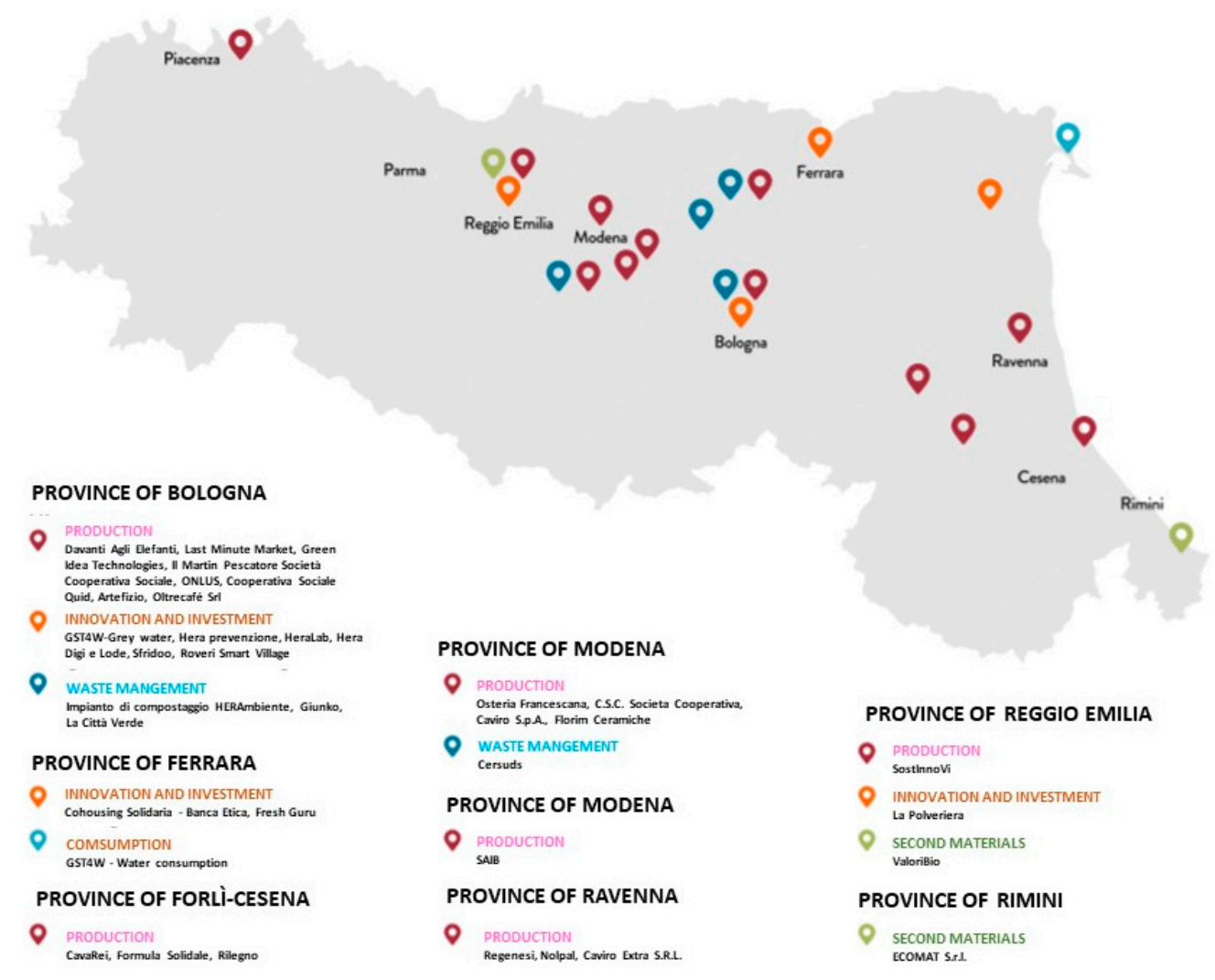

Figure 7. CE initiatives in the Emilia-Romagna Region. Source: Data from reference [29].

The province of Bologna has the largest number of good practices, followed by Modena, Ferrara, Reggio Emilia and Forli-Cesena. In contrast, the number of good practices located in the provinces of Piacenza, Rimini and Ravenna is even less. The analysis of the field of application of the selected good practices (divided between production, consumption, innovation and investment, waste management and secondary materials) has a concentration in the application in the field of production (19), followed by innovation and investment (9) and from waste management and secondary materials ( 3 each). Currently, the application of $\mathrm{CE}$ intended for consumption includes only one good practice.

The reference sectors of the Emilia-Romagna good practices (the same good practice can pertain to several sectors, even different ones) are very heterogeneous. The sector 
Repair, Reuse and Refurbishment includes the largest number of good practices (13), followed by Utilities (6), Recycling and Bio-based Industries (5 each), Home Furnishings, Sustainable Development and Building/Construction (4 each). The remaining sectors have fewer good practices.

A reflection concerns the heterogeneity of the sectors to which good practices pertain. The variety of sectors indicates that the $\mathrm{CE}$ is confirmed as a multi-sectoral approach that leads to a systemic innovation of the entire production system. Another reflection concerns the field of application of good CE practices. It emerges that the initiatives are not just about waste management, which remains a small part of the $\mathrm{CE}$, considering that to reduce at the maximum the residues is one of the CE's primary goals. Most of the best practices are applied to production processes. In particular, the Repair, Reuse and Restructuring sector emerges. This result confirms that the CE promotes the prevention of waste, facilitating the closure of cycles and extending the life of products.

This analysis on enhancing existing good CE practices in the Emilia-Romagna region level is a first attempt to systematise a continually growing and evolving reading. Therefore; the research is not exhaustive and is based on initiatives identified by platforms and CE studies active at the national level in 2019.

\subsubsection{Areas of Interest in Emilia-Romagna Region for Future Initiatives}

To encourage the transition to a CE, we identified the main gaps that limit its implementation for two sectors that play a fundamental role within the Italian and Emilia-Romagna Region: Plastic and Textile sectors. In these sectors, there is maximum attention given the need to reduce the environmental impact. These sectors are the industry of plastics and the textile industry. For these two, the limits and aspects still to be developed to transition to a CE are highlighted to determine the skills and tools needed to find the most appropriate solutions.

In the Plastic Sector, two types of plastic products, packaging and disposable (single use), concentrate most of the efforts of numerous companies in the sector in the EmiliaRomagna region. In particular, the main aspects on which to work more for the development of an effective $\mathrm{CE}$, as follows:

(i) Plastic materials are easily workable and customisable according to functional and aesthetic needs, even particular ones. The lack of one standardisation of this material's production characteristics has determined, in recent decades, the presence of multiple types of plastics (very often combined), which considerably complicate the phases of consumption, i.e., collection, separation and recycling. It follows therefore that two priority aspects on which to act are: (a) the definition of technical specifications that can reduce the differences in raw material without affecting the quality of the products; (b) strong product redesign (e.g., mono-material plastic products, transparency, ability to increase the shelf-life of food products);

(ii) The second point concerns the improvement of the infrastructure for the collection of plastic after its use: digitalisation and innovative technologies typical of the current industrial context can guarantee the traceability of produced even after consumption, thus avoiding the dispersion of these materials into the environment;

(iii) There is a need to increase the quantity and improve the quality of recycled plastics. Product redesign can help development in this direction. Still, it is also necessary to improve the plant technology for selecting and recycling plastics, trying to bring a second raw material with the same characteristics as the virgin one. This way it is possible to increase the demand for recycled plastics (now stopped at $6 \%$ ) and potentially also reduce the price, to make it more competitive than the virgin raw material;

(iv) It is also necessary to consider the logistical aspects that a significant impact (both economic and environmental) on circular initiatives;

(v) All the previous points must be supported by a practical one legislation that favours the use of waste considering it as resources, below sure conditions that guarantee compliance with all the quality and safety standards required by the product; 
Finally, among the environmental impact generated by the plastics sector, the microplastic problem is increasingly felt. On this topic, the necessary research work is still high to determine the leading causes, characterise such materials and finally find technological solutions to reduce its impact.

Concerning the Textile Sector, the transition to a CE is recognised as an opportunity to obtain environmental, economic and social benefits. The main actions, withheld as effective for moving to a CE in the textile sector, concern: (i) the redesign of the product and process to minimise waste before and after consumption, reduce energy consumption and make the use of resources more efficient; (ii) the use of recyclable and/or biodegradable materials; (iii) the use of techniques that promote recovery of post-consumer materials and the reduction of the release of harmful substances (design for recycling; design for monomateriality, design for disassembly, design for zero toxicity). Regarding the distribution and use of textile products from a CE perspective, the pay-per-use method is increasingly used, which aims to extend the product life: leasing, sharing, and repair service are increasingly widespread within the sector.

Despite this, three main obstacles slow down the textile sector's transition towards a CE: the first is technical-economic; the second is related to the supply chain's infrastructure and the third is linked to the market.

(i) From a technical-economic point of view, one of the main barriers preventing the closing of the cycle is the lack of commercially available technologies usable to recycle textile residues and the separation of composite fibres. It follows that the technologies currently used make it possible to obtain low quality recycled materials. Furthermore, these processes are costly as well must be combined with high logistical costs to transport the material to recycling plants, still not very widespread.

(ii) The speed and extent to which the textile supply chain can move to a circular model depend on the knowledge, awareness and involvement of all the players operating within the sector. One of the biggest obstacles for the textile sector is given by the number and diversity of the players involved throughout the supply chain. The textile sector is complex and includes several very different sectors, in type and size, that operate in a more or less structured way within a very complex and dynamic supply chain. For this reason, it is not easy to achieve supply chain integration, through the sharing of objectives and the exchange of useful information. Yet, without appropriate infrastructure, it is not easy to align with the criteria for a strong product and process redesign. In this case, the traceability of resources is lost downstream.

(iii) Although the consumer is increasingly attentive to the issue of sustainability and the environmental impact generated by the production of textile products, fabrics recovered, reused and recycled are perceived as low quality and their demand is still relatively low. Therefore, it is necessary to incentivise the consumer and raise awareness that textile products can be recovered and recycled to extend the life of these resources. Similar to the case of plastics, the standardisation of the characteristics of raw materials e of secondary raw materials can facilitate the maintenance of the quality of the resources and increase acceptance also by end-users.

\subsection{Discussion of Results and Agenda for Further Studies}

The transition to the $\mathrm{CE}$ requires a radical change in the way in which we produce and consume. Each actor will have to play a key role in the coming years. Research, designing products given the future reuse of materials or maintaining its value, improving durability, upgradeability, repairability and reusability. The companies develop business models that generate revenues from waste valorisation to dematerialisation and the provision of services and/or products. Consumers choose products that favour the closing of the cycle, use them efficiently and dispose of them adequately to trigger a continuous improvement of companies-consumers and the other way around. Public and financial institutions will have to facilitate the transition process with clear rules, concessions, incentives, and proper credit access. 
Unfortunately, the desired transition faces some barriers on the way, the results of this study found the results as $[7,8,37]$ in the Emilia-Romagna region, such as (i) Financial/Economic; (ii) Structural; (iii) Operational; (vi) Technical and technological; (v) Regulatory; (vi) Market.

Another critical aspect to account in the CE transition is related to citizens' awareness and participation. This study did not analyse this group of stakeholders' perceptions in the process of transition in the Emilia-Romagna Region. In fact, this study was focused on other stakeholders' perceptions, particularly local government, industry and academia, considering a market orientation (as in [17]).

We should highlight that the political and territorial orientation could be integrated to provide a holistic view of the transition towards a CE, bringing light to the integration of businesses with citizens' demands in terms of urban organisation. However, it was not the focus of the study at this moment. So, future studies in the Emilia-Romagna region should consider the citizens perspective in terms of democratisation of the transition, for example, planning the design of the cities and regions under an urban metabolism perspective, aiming to be more inclusive and socially equitative, similarly to the studies conducted by [30-35].

Although there are barriers to be overcome, the Region of Emilia-Romagna presented some great efforts to enable the transition towards a CE in terms of the market orientation. The region was the first in Italy to approve a law on the CE, Law no. 16 of 5 October 2015 [45,46]. This law was born from a process involving Local Authorities, associations and territories under other forms of stakeholders. Based on the CE's essence, the law pays attention to the entire life cycle of products. It connects the demand and supply of secondary raw materials, according to the territorial production characteristics and the already active register of the Chambers of Commerce. Three are the fields of action: (i) more sustainable waste management; (ii) more information to create a new civic awareness and, (iii) new financial instruments (both for the public administration and for businesses).

The objectives set are quite ambitious, even higher than those established by the European Union in 2015 in the first action plan (those established by the new action plan of March 2020): (i) reduction of per capita waste production of 20-25\% by 2020; (ii) waste collection of $73 \%$ by 2020; (iii) 70\% recycling by 2020 (65\% of municipal waste by 2030 for the EU) and, (iv) landfill less than $5 \%$ by 2020 (10\% by 2030 for the EU).

The initiatives of the Emilia-Romagna Region filled a gap pointed out by [17], which emphasises the importance of studies approaching the regional level of countries in terms of market orientation and discussions concerning the opportunities challenges presented by circularity. The results found in the project entitled "Accelerare la transizione verso l'economia circolare in Emilia-Romagna: Uno studio sullo stato dell'arte, le competenze e i bisogni tecnologici e finanziari" [29] can be used as a benchmarking for other regions in Italy and even, in European countries.

The initiatives in terms of financial instruments demonstrated that the CE is a priority for the Emilia-Romagna Region. In addition to the initiatives developed independently, financial and credit institutions can undoubtedly benefit from the strengthening of partnerships with recognised entities and figures to carry out cultural and awareness-raising activities and deepen evaluation criteria for CE processes to develop more operational initiatives. Today, the credit world is carrying out some experiments through which structure tools and skills for the benefit of customers who want to develop CE processes. The two most prominent examples, for the Italian and European panorama, are: Banca Etica e Intesa SanPaolo.

The existing infrastructure in terms of technological and scientific skills mapped in the Emilia-Romagna Region demonstrated that it covers the entire life cycle of the product, ranging from design, to process technologies up to the evaluation methodologies of environmental impacts and the valorisation of waste and by-products, as emphasised by [3], without focusing only in waste management as it occurs in several countries. This result corroborates the ongoing initiatives spread in the territory, which denotes a strong 
partnership between the research centres, academia and companies, motivated by projects developed in the region.

The focus of interest for further projects and initiatives in the region are the Plastics and Textiles Sectors, which still needs to stimulate more efforts to make the transition towards a CE reality and, a gap remains related to the gathering of information required to the measure of the circularity of product processes and companies, as mentioned by $[13,14]$. The primary plastics' relevance was pointed out specifically by Reinwaste outcomes as the primary source of improvement in the agriculture and food industry, oriented to the adoption of sustainable-and economically favourable technologies to reduce the component of inorganic waste such as packaging mulch and similar materials.

Another aspect to highlight is related to the analysis of governance approach, which is centred on public-private bodies, considering the perspective of business, policy and civil society actors, as pointed out by [33]. Other governance approaches can be exploited in future studies, considering the interests of different groups of stakeholders, such as consumers, citizens and social organisations.

\section{Conclusions}

This study intended to analyse the efforts aimed at the transition to a CE in the EmiliaRomagna Region, Italy, considering technological, legal-regulatory, and financial points of view under a market orientation as found through the project conducted by ART-ER, entitled "Accelerare la transizione verso l'economia circolare in Emilia-Romagna: Uno studio sullo stato dell'arte, le competenze e i bisogni tecnologici e finanziari" [29], considering the market orientation in the context of the adaptation efforts required from the companies, academia and local Government to attend the new demands of the market.

As the main results of this study, we can point out the synthesis of the regulatory overview related to CE at European, Italian and Regional (Emilia-Romagna) levels, besides describing the main financial instruments and Technical-scientific infrastructure and resources dedicated to $\mathrm{CE}$ in the region. Furthermore, we highlight the needs of productive sectors in the Emilia-Romagna Region. Finally, we identified the main initiatives and areas of interest related to the CE.

It is possible to perceive that the knowledge of the concept of $\mathrm{CE}$ and the awareness that the transition towards this paradigm is fundamental and capable of generating several benefits are now quite widespread in the Emilia-Romagna Region. However, some barriers have to be faced and, investments to be made, mainly in identified priority sectors, which are the Plastic and Textiles sectors.

This study is limited to approaching the barriers, production system needs, existing initiatives, technological, legal-regulatory and financial points of view of the Emilia-Romagna region under a market orientation. Studies observing the same factors in other European or Italian Regions can find different results. Besides, the political or territorial orientations were not approached as a lens of our analysis. Another limitation is related to the group of stakeholders considered in our study, which was mostly formed by participants from the local government, industry and academia. Further studies can analyse the same aspects related to market orientation in other Italian Regions and conduct surveys with citizens/consumers to identify their perception related to the transition towards a CE, analysing the democratisation of the transition under a political and territorial orientation.

Some studies approached the CE in cities considering the political and territorial orientation such as [31,32], however as mentioned by [17] still there are few studies aimed to analyse the transition towards a $\mathrm{CE}$ on regions, considering the market orientation aimed to study novel business models, new products and, processes. So, in terms of theoretical contributions, this paper fills this gap and contributes to the debate in regions, approaching the transition towards a CE considering the market orientation lens, and the reality of a prominent region in Italy, and also, taking into account the perceptions of several stakeholders from local Government, industry and academia. It is essential to study the market orientation considering the social impacts generated with the economic 
development in regions, translated in increasing of jobs, income and the reinvestment of taxes in the community, which can benefit the citizens directly generating a better infrastructure.

In terms of practical contributions, this paper can be useful for researchers and practitioners acting in this field, because it synthesises the existing knowledge related guidelines and legislation in Europe and Italy, the initiatives related to the transition towards the $\mathrm{CE}$ in the Emilia-Romagna Region bringing light to the main stakeholders involved, the financial instruments used, the technical-scientific skills needed, the production system demands, the existing initiatives and primary areas of interest. It can be used as a guide to analyse the same elements in other regions in Italy, or even in Europe, as well as a basis for public and private policymakers and researchers interested in the transition towards a $\mathrm{CE}$ at the macro-level, considering regions, under a perspective of market orientation.

Author Contributions: A.B. conducted the writing of the initial draft preparation and the study's supervision. J.R. conducted the writing of the original draft preparation and formal analysis of the results. F.F., P.G., S.P. and D.S. contributed to the writing-review. All authors have read and agreed to the published version of the manuscript.

Funding: ART-ER PAC 2020_Programma Annuale Consortile approvato nell'Assemblea dei Soci, 20 Dicembre 2019, financed by Por Fesr 2014-2020_Programma operativo regionale-Fondo europeo di sviluppo regionale.

Institutional Review Board Statement: Not applicable.

Informed Consent Statement: Not applicable.

Data Availability Statement: The data presented in this study are available on request from the corresponding author. The data are not publicly available due to the standards of the partners involved in the project.

Acknowledgments: The authors are grateful for the institutions supporting this study: ReinwasteRemanufacture the food supply chain by testing Innovative solutions for zero inorganic waste. (https:/ / reinwaste.interreg-med.eu/), financed by the European Commission by means of INTERREG MED programme.

Conflicts of Interest: The authors declare no conflict of interest.

\section{References}

1. Reike, D.; Vermeulen, W.J.; Witjes, S. The circular economy: New or Refurbished as CE 3.0? Exploring Controversies in the Conceptualisation of the Circular Economy through a Focus on History and Resource Value Retention Options. Resour. Conserv. Recycl. 2018, 135, 246-264. [CrossRef]

2. Homrich, A.S.; Galvao, G.; Abadia, L.G.; Carvalho, M.M. The circular economy umbrella: Trends and gaps on integrating pathways. J. Clean. Prod. 2018, 175, 525-543. [CrossRef]

3. Korhonen, J.; Honkasalo, A.; Seppälä, J. Circular economy: The concept and its limitations. Ecol. Econ. 2018, 143, 37-46. [CrossRef]

4. Ridaura, G.; Llorens-Cervera, S.; Carrillo, C.; Buj-Corral, I.; Riba-Romeva, C. Equipment suppliers integration to the redesign for emissions reuse in industrial processes. Resour. Conserv. Recycl. 2018, 131, 75-85. [CrossRef]

5. Zacho, K.O.; Mosgaard, M.; Riisgaard, H. Capturing uncaptured values-A Danish case study on municipal preparation for reuse and recycling of waste. Resour. Conserv. Recycl. 2018, 136, 297-305. [CrossRef]

6. Guarnieri, P.; Cerqueira-Streit, J.A.; Batista, L.C. Reverse logistics and the sectoral agreement of packaging industry in Brazil towards a transition to circular economy. Resour. Conserv. Recycl. 2020, 153, 104541. [CrossRef]

7. Ritzen, S.; Sandstrom, G.O. Barriers to the Circular Economy-Integration of perspectives and domains. Procedia CIRP 2017, 64, 7-12. [CrossRef]

8. Kirchherr, J.; Piscicelli, L.; Bour, R.; Kostense-Smit, E.; Muller, J.; Huibrechtse-Truijens, A.; Hekkert, M. Barriers to the circular economy: Evidence from the European Union (EU). Ecol. Econ. 2018, 150, 264-272. [CrossRef]

9. Tura, N.; Hanski, J.; Ahola, T.; Ståhle, M.; Piiparinen, S.; Valkokari, P. Unlocking circular business: A framework of barriers and drivers. J. Clean. Prod. 2019, 212, 90-98. [CrossRef]

10. Zhu, Q.; Geng, Y. Drivers and barriers of extended supply chain practices for energy saving and emission reduction among Chinese manufacturers. J. Clean. Prod. 2013, 40, 6-12. [CrossRef]

11. Cuerva, M.C.; Triguero-Cano, Á.; Córcoles, D. Drivers of green and non-green innovation: Empirical evidence in Low-Tech SMEs. J. Clean. Prod. 2014, 68, 104-113. [CrossRef] 
12. Ilić, M.; Nikolić, M. Drivers for development of circular economy-A case study of Serbia. Habitat Int. 2016, 56, 191-200. [CrossRef]

13. Bianchini, A.; Rossi, J.; Pellegrini, M. Overcoming the Main Barriers of Circular Economy Implementation through a New Visualization Tool for Circular Business Models. Sustainability 2019, 11, 6614. [CrossRef]

14. Rossi, J.; Bianchini, A.; Guarnieri, P. Circular Economy Model Enhanced by Intelligent Assets from Industry 4.0: The Proposition of an Innovative Tool to Analyse Case Studies. Sustainability 2020, 12, 7147. [CrossRef]

15. European Comission. Communication from the Commission to the European Parliament, the European Council, the Council, the European Economic and Social Committee and the Committee of the Regions. The European Green Deal; COM(2019) 640 Final; European Commission: Brussels, Belgium, 2019. Available online: https://ec.europa.eu/info/sites/info/files/european-green-dealcommunication_en.pdf (accessed on 4 April 2020).

16. European Commission. Communication from the Commission to the European Parliament, the Council, the European Economic and Social Committee and the Committee of the Regions. A New Circular Economy Action Plan for a Cleaner and More Competitive Europe; COM/2020/98 Final; European Commission: Brussels, Belgium, 2020. Available online: https: / / eur-lex.europa.eu/legal-content/ EN/TXT/?uri=COM\%3A2020\%3A98\%3AFIN (accessed on 21 March 2020).

17. Vanhamäki, S.; Virtanen, M.; Luste, S.; Manskinen, K. Transition towards a circular economy at a regional level: A case study on closing biological loops. Resour. Conserv. Recycl. 2020, 156, 104716. [CrossRef]

18. Geissdoerfer, M.; Savaget, P.; Bocken, N.M.P.; Hultink, E.J. The Circular Economy-A new sustainability paradigm? J. Clean. Prod. 2017, 143, 757-768. [CrossRef]

19. Ghisellini, P.; Cialani, C.; Ulgiati, S. A review on circular economy: The expected transition to a balanced interplay of environmental and economic systems. J. Clean. Prod. 2016, 114, 11-32. [CrossRef]

20. Genovese, A.; Acquaye, A.A.; Figueroa, A.S.C.; Koh, L. Sustainable supply chain management and the transition towards a circular economy: Evidence and some applications. Omega 2017, 66, 344-357. [CrossRef]

21. Kirchherr, J.; Reike, D.; Hekkert, M. Conceptualising the circular economy: An analysis of 114 definitions. Resour. Conserv. Recycl. 2017, 127, 221-232. [CrossRef]

22. Pauliuk, S. Critical appraisal of the circular economy standard BS 8001: 2017 and a dashboard of quantitative system indicators for its implementation in organisations. Resour. Conserv. Recycl. 2018, 129, 81-92. [CrossRef]

23. Picone, S.; Sani, D. Transitioning to Circular Economy in Emilia-Romagna, a pilot quadruple helix study. In Proceedings of the III International Triple Helix Summit, Bologna, Italy, 24-26 November 2020. Available online: https: / / triplehelixsummit2020. triplehelixassociation.org/ (accessed on 12 October 2020).

24. Merli, R.; Preziosi, M.; Acampora, A. How do scholars approach the circular economy? A systematic literature review. J. Clean. Prod. 2018, 178, 703-722. [CrossRef]

25. European Commission. Communication from the Commission to the European Parliament, the Council, the European Economic and Social Committee and the Committee of the Regions. Closing the Loop-An EU Action Plan for the Circular Economy, Circular Economy Package; COM/2015/614 Final; European Commission: Brussels, Belgium, 2015. Available online: https:/ / eur-lex.europa.eu/ legal-content/EN/TXT/?uri=CELEX\%3A52015DC0614 (accessed on 21 March 2020).

26. ECESP_European Circular Economy Stakeholder Platform. Available online: https://www.eesc.europa.eu/sites/default/files/ files/qe-04-18-972-en-n.pdf (accessed on 4 April 2020).

27. ICESP-Italian Circular Economy Stakeholder Platform. Available online: https:/ /www.icesp.it/ (accessed on 4 April 2020).

28. Italian National Committee for Biosafety, Biotechnology and Sciences of Life. Implementation Action Plan (2020-2025) for the Italian Bioeconomy Strategy BIT II. Available online: http:/ / cnbbsv.palazzochigi.it/en/areas-of-work/bioeconomy / (accessed on 12 October 2020).

29. ART-ER S. Cons. p. A-Attrattività Ricerca Territorio è la Società. Accelerare la Transizione Verso L'economia Circolare in EmiliaRomagna: Uno Studio Sullo Stato Dell'arte, le Competenze e i Bisogni Tecnologici e Finanziari. Regione Emilia-Romagna: Marzo. 2020. Available online: https:/ / www.art-er.it/2020/05/economia-circolare-accelerare-la-transizione-verso-un-nuovo-modello/ (accessed on 12 October 2020).

30. Prendeville, S.; Cherim, E.; Bocken, N. Circular cities: Mapping six cities in transition. Environ. Innov. Soc. Transit. 2018, 26, 171-194. [CrossRef]

31. Kębłowski, W.; Lambert, D.; Bassens, D. CE and the city: An urban political economy agenda. Cult. Organ. 2020, 26, 142-158. [CrossRef]

32. Fratini, C.F.; Georg, S.; Jørgensen, M.S. Exploring CE imaginaries in European cities: A research agenda for the governance of urban sustainability transitions. J. Clean. Prod. 2019, 228, 974-989. [CrossRef]

33. Kenis, A.; Bono, F.; Mathijs, E. Unravelling the (post-) political in transition management: Interrogating pathways towards sustainable change. J. Environ. Policy Plan. 2016, 18, 568-584. [CrossRef]

34. Marin, J.; De Meulder, B. Urban landscape design exercises in urban metabolism: Reconnecting with Central Limburg's regenerative resource landscape. J. Landsc. Archit. 2018, 13, 36-49. [CrossRef]

35. Marin, J.; De Meulder, B. Interpreting circularity. Circular city representations concealing transition drivers. Sustainability 2018, 10, 1310. [CrossRef]

36. Perron, G.M. Barriers to Environmental Performance Improvements in Canadian SMEs. Ph.D. Thesis, Dalhousie University, Halifax, NS, Canada, 2005. 
37. De Jesus, A.; Mendonça, S. Lost in transition? Drivers and barriers in the eco-innovation road to the circular economy. Ecol. Econ. 2018, 145, 75-89. [CrossRef]

38. EPRS-European Parliamentary Research Service (Didier Bourguignon). Circular Economy Package: Four Legislative Proposals on Waste. Available online: https:/ /www.europarl.europa.eu/RegData/etudes/BRIE/2018/625108/EPRS_BRI(2018)625108_EN. pdf (accessed on 12 October 2019).

39. Ministero Dell'ambiente e della Tutela del Território e del Mare e Ministero dello Sviluppo Economico (Ministry of the Environment and Protection of the Territory and the Sea, and the Ministry of Economic Development). Towards a Circular Economy model for Italy: Overview and Strategic Framework. Available online: http:/ / consultazione-economiacircolare.minambiente.it/ sites/default/files/TOWARDS\%20A\%20MODEL\%20eng\%20COMPLETO.pdf (accessed on 20 September 2019).

40. Osservatorio Green Economy. La Green Economy in Emilia-Romagna (The green Economy in Emilia-Romagna Region). Available online: http://www.ervet.it/wp-content/uploads/downloads/2019/01/Ervet_Volume_Green_Economy_WEB_rev. pdf (accessed on 10 May 2020).

41. European Parliament. Directive (EU) 2018/8497 of the European Parliament and of the Council, 30th May 2018, Modifies the 2000/53/EC Directives Relating to End-of-Life Vehicles, 2006/66/EC Relating to Batteries and Accumulators and to Waste Batteries and Accumulators e 2012/19/EU on Waste Electrical and Electronic Equipment. Available online: https:/ / eur-lex. europa.eu/legal-content/IT/TXT/?qid=1585045569536\&uri=CELEX:32018L0849 (accessed on 15 November 2019).

42. European Parliament. Directive (EU) 2018/850 of the European Parliament and of the Council, of 30th May 2018, Amends Directive 1999/31/EC on Landfills of Waste. Available online: https:/ / eur-lex.europa.eu/legal-content/IT/TXT/?qid=15850456 14229\&uri=CELEX:32018L0850 (accessed on 21 March 2019).

43. European Parliament. Directive (EU) 2018/851 of the European Parliament and of the Council, of 30th May 2018, Amends Directive 2008/98/EC on Waste. Available online: https:/ / eur-lex.europa.eu/legal-content/IT/TXT/?qid=1585045651752\&uri= CELEX:32018L0851 (accessed on 21 March 2019).

44. European Parliament. Directive (EU) 2018/852 of the European Parliament and of the Council of 30th May 2018, Amends Directive 94/62/EC on Packaging and Packaging Waste. Available online: https:/ / eur-lex.europa.eu/legal-content/IT/TXT/ ?qid=1585045681321\&uri=CELEX:32018L0852 (accessed on 21 March 2019).

45. Gazzetta Ufficiale. Legge 221 del 28 Dicembre 2015, Recante “Disposizioni in Materia Ambientale per Promuovere Misure di Green Economy e per il Contenimento Dell'uso Eccessivo di Risorse Naturali. (Law 221 of 28 December 2015, Containing "Environmental Provisions to Promote Green Economy Measures and for the Containment of Excessive Use of Natural Resources). c.d. "Collegato Ambientale" alla Legge di Stabilità 2016, G.U. December 15, n. 13. Available online: https: / /www.gazzettaufficiale it/eli/id/2016/1/18/16G00006/sg (accessed on 21 March 2019).

46. Regione Emilia-Romagna. Legge Regionale n. 16 del 5 Ottobre 2015. Disposizioni a Sostegno Dell'economia Circolare, della Riduzione della Produzione dei Rifiuti Urbani, del Riuso dei Beni a Fine Vita, della Raccolta Differenziata e Modifiche alla Legge Regionale 19 Agosto 1996 n. 31-Disciplina del Tributo Speciale per il Deposito in Discarica dei Rifiuti Solidi. (Regional Law n. 16 of 5 October 2015. Provisions in Support of the Circular Economy, the Reduction of Urban Waste Production, the Reuse of Goods at the End of Their Life, Separate Collection and Amendments To Regional Law no. 31). Available online: http:/ / bur.regione.emilia-romagna.it/dettaglio-inserzione?i=e08c3ac15eeb4fb1902978ea32f39a72 (accessed on 21 March 2019).

47. Regione Emilia-Romagna. Regional Waste Plan of Emilia-Romagna Region. Delibera dell'Assemblea Legislativa della Regione Emilia-Romagna n.67 del 3 Maggio 2016. Decisione sulle Osservazioni Pervenute e Approvazione del Piano Regionale di Gestione dei Rifiuti (PRGR). Available online: http:/ / bur.regione.emilia-romagna.it/dettaglio-inserzione?i=373a74a217424303bfeb8e18223 b4cb9 (accessed on 21 March 2019).

48. Wittmayer, J.M.; Schäpke, N. Action, research and participation: Roles of researchers in sustainability transitions. Sustain. Sci. 2014, 9, 483-496. [CrossRef]

49. EMF-The Ellen MacArthur Foundation. Circular Economy Overview. Available online: https://www.ellenmacarthurfoundation. org/circular-economy / overview / concept (accessed on 30 September 2019). 